\title{
Islam's increased visibility in the European public sphere A real crisis?
}

\author{
DIDEM DOGANYILMAZ DUMAN
}

\begin{abstract}
I is believed that the massive flow of refugees and dramatically increased asylum applications from Muslim societies to member countries of the European Union will cause significant change in the demographic characteristics of those countries. Although the presence of Muslims is not a recent phenomenon in Europe, their increased visibility has become once again a dominant political discourse for right-wing political parties. The important question is whether the Muslim presence has become a component of the post-truth politics of the political leaders of these parties, or whether it constitutes a real threat to European society. Does the European Union, then, face a real crisis? If so, what is the nature of the crisis - is it a refugee crisis, an identity crisis, or even worse, is it a crisis of tolerance? This paper analyses the political atmosphere and its effects on society in terms of an increased visibility of Muslims and Islamic symbols in the European public sphere in order to answer those questions.
\end{abstract}

The massive flow of refugees and dramatically increased numbers of asylum applications from Muslim societies to member countries of the European Union (EU) have attracted attention, with utmost ascendancy being given to Muslim-Christian relations involving certain debates which already have a long history. Already existing Muslim populations have been the focus of conspiracy theories concerning significant changes in the demographic characteristics of European societies, and recently negative perceptions of Muslims in Europe have been re-awakened. However, neither the existence of the negative perceptions, nor of Muslims in Europe, are recent phenomena. Muslims have been coming in to Europe from various countries since the second half of the twentieth century. The numbers of Muslims in the EU countries and the ratios of the Muslim population overall for each country are shown in Chart I. By December 20 I5, the United Nations High Commissioner for Refugees (UNHCR) declared that almost a million people had crossed the Mediterranean Sea; they are predominantly Syrian, most of the rest are Iraqis and Afghans, but in total, they are all Muslims (Clayton and Holland 2015). The numbers and ratios in the figures have 
increased; but, is it just recent events that have led to this population growth or is there anything that has changed since the second half of the twentieth century, when the first immigrants arrived?

During the first decades following their immigration, Muslims had lived within their own isolated settlements, alongside other Muslim immigrants, working in designated jobs. Their presence was certain; however, they were not fully integrated into the local culture. They had led invisible lives outside of certain areas of the public sphere. In subsequent generations, they began to become more visible as they started to integrate and enjoy the same public services as their neighbouring communities. They started to go beyond the boundaries that had been drawn for their parents. The younger generation became more visible in schools in various areas of the education system and as a consequence of an avowed equality of education, the younger generation of immigrants also started to take on the same jobs as their neighbours. Equal education and shared work spaces led to increased interaction between the two groups; hence, the public sphere has become one that is shared among immigrant Muslims and locals. The public sphere possesses significance since it provides an opportunity for reflective discussions in the local culture. Hence, the visibility of Islamic symbols, along with Muslims' presence, has changed the local communities in that whilst they occupy the same place they do so with different sets of values. As quoted by Nilüfer Göle (2015: 97), the real concern does not coincide with the presence of Muslims, which after all dates further back in history; it begins at the point where Muslims become involved in the local culture. Those living in the suburbs were considered to be out of the system; but Muslims who present their cultural and religious differences personally in the public sphere by speaking the local language and working as colleagues with the locals cause uneasiness. These fully integrated Muslims are conscious of their rights to live according to their own religion and have the confidence to demand these rights. Sharing the same era in the same sphere with Muslims has particularly affected Europeans (Göle 20 го: I 5). With visible involvement of Muslims in local cultures in Europe, the transformation of the European public sphere becomes a subject of debate since the change can clearly be seen (Soliman 20I7). Within this context of interaction, Islam is becoming more and more involved in the European public sphere and consciousness (Göle 2oro: 66). 
With the separation of Church and state and encouragement of gender equality, the European public sphere possesses secular characteristics; hence the involvement of new religious symbols has brought about negative results in terms of Christian-Muslim relations. The Islamic form of dress, for instance, is considered to be antagonistic to modern values, since modernity has been thought to be synonymous with Western values (Göle 2010: IO7). Consequently, in a secular public sphere, the presence of veiled women has brought about uneasiness. Since the late r 980 , Islam and its symbols have brought about controversy in European countries where they are seen to be undermining the order, and due to its unwelcome presence the involvement of Islam in the European public sphere has been perceived to be constrained (Göle 2015: 36-7).

The reaction to this situation among locals, which has been unfavourable, to the aforementioned constrained involvement of Islam in the secular European public sphere has become a political tool which right-wing populism has started to focus on. There have been various labels to highlight these populist moments that, with references to the extreme right or populist right, form one single family (Muis and Immerzeel 20 I 7: 910). This family has wielded its political influence, in addition to its descriptive characteristics - which have been introduced by Jens Rydgren (2005: $32-7,58-69)$ as ethno-nationalist with reference to xenophobia and exclusionist in favouring its own people for certain examples - in order to mobilise societies in various European countries. Within this context, it is also important to highlight the Eurosceptic characteristics of this family. The term has been defined by Paul Taggart (1 998: 366) as 'the idea of contingent or qualified opposition, as well as incorporating outright and unqualified opposition to the process of European integration'. Taggart and Aleks Szczerbiak (2002: 7) have categorised Euroscepticism, and introduced 'hard Euroscepticism', as opposition to the EU as well as the whole project of European integration and support for withdrawal from membership in contrast to 'soft Euroscepticism' which was not a principled objection to European integration while possessing concerns about one or a number of policy areas in terms of conflict with national interests. With various critics of hard and soft Euroscepticism, Petr Kopecky and Cas Mudde (2002) have suggested a different classification in terms of support for European integration and the EU itself. They have introduced four concepts, which are: Euroenthusiasts (EU-optimist and Europhile), Europragmatists (EU-optimist but Europhobe), Eurosceptics 
(EU-pessimists and Europhiles), and lastly Eurorejects (EU-pessimist and Europhobe). The political parties on which this research focus have been mostly categorised as hard Eurosceptic by Taggart and Szczerbiak in their analysis, and it would not be wrong to label them as Eurorejects with respect to the analysis of Kopecky and Mudde, due to their negative approaches towards the EU.

As far back as the involvement of Islam in the European public sphere and unfavourable interactions between newcomer Muslims and local Christians date, so far back do the existence of right-wing populist parties date as well (Mudde 2012). However, the debate has gained importance recently as a result of new so-called 'threats'. While the massive flow of refugees heading to the European countries as a consequence of the Arab Spring and ensuing Syrian Civil War has brought about concerns in terms of identity, attacks carried out by the Islamist terrorist group Islamic State of Iraq and Levant (ISIL) have brought about concerns in terms of security. Eventually the EU has applied certain new rules including asylum applications, Schengen Area trespass regulations, and the reintroduction of border patrols (Rankin 2016, Nielsen 2017). In addition to these applications, the EU-Turkey statement was agreed on I 8 March 2016 in order to end irregularities in the flow and to keep refugees within Turkey; in other words outside the EU borders (European Commission 2016). Not only has the disbursement of three billion euros to Turkey in return for keeping them within its borders (European Commission 2016) been criticized strongly, but so also has the context of the statement alongside recent applications within the frame of human rights; however, they have perfectly matched the anti-immigrant and anti-Islamic discourses of the right-wing populist parties' representatives among EU member states. They have brought about an increase in their support by highlighting recent developments as being favourable to their ideology, which focuses on repatriating migrants in order to maintain homogeneous structures free from a supranational sovereignty - that is to say, the EU - and newcomer refugees.

This paper analyses the political atmosphere in the EU with specific examples of right-wing populist parties which have gained power in member countries within the context of the presence of Muslims. Alongside many other discourses, the ones based on anti-immigrant and anti-Islamic policies and the consequent support that they attract will be taken into consideration in comparison with the values of the EU itself. As a background, 
a short overview is provided of the core concepts that the research questions are based on and, to complete the analysis, the instant reaction of the society has been analysed. To facilitate this, in addition to scholarly papers, newspaper articles have been taken into consideration. Instead of suggesting a solution to the process of social polarisation occurring as a consequence of the interaction between local Christians and newcomer Muslims, this paper attempts to answer the following questions: Do these concerns, related to the presence of Muslims, highlight a real threat to the EU, as repeatedly mentioned, or is it simply another aspect of the post-truth politics that right-wing populist parties follow? If there is a real threat to the EU, what is it exactly?

\section{Theoretical background}

The roots of Islam in continental Europe have two different provenances: immigration, and historical settlement policies. Immigration is a recent phenomenon beginning in the twentieth century and mostly directed towards western and northern European countries. Muslim presence in certain countries such as Germany, France, Belgium the Netherlands and the Scandinavian countries is mostly related to immigration. Chart I demonstrates the ratio of the Muslim population overall. On the other hand, historical settlement policies play a significant role in terms of Muslim presence in eastern European, most specifically in the Balkan countries. As a result of the settlement policy of the Ottoman Empire, which was applied from the very beginning of the fifteenth century with the conquest of Thrace, Islam became a component of religious diversity in eastern countries (Doganyilmaz Duman 20 I6). As the presence of Islam was maintained for centuries, Muslims have become localized in certain eastern European countries.

In contrast to already existing Muslim populations in eastern European countries, immigration of Muslims to western European countries since the second half of the twentieth century has brought about uneasiness among local Christians, as aforementioned. With significant increases in the Muslim populations, and their involvement in the public sphere, a new debate was opened in terms of a demographic shift within European societies. The debate was concerned with the effects of Islam on European identity, which would be undermined due to the presence of Muslims; eventually, Europe would be Islamized. Bat Ye'or (2005) introduced a conspiracy theory 


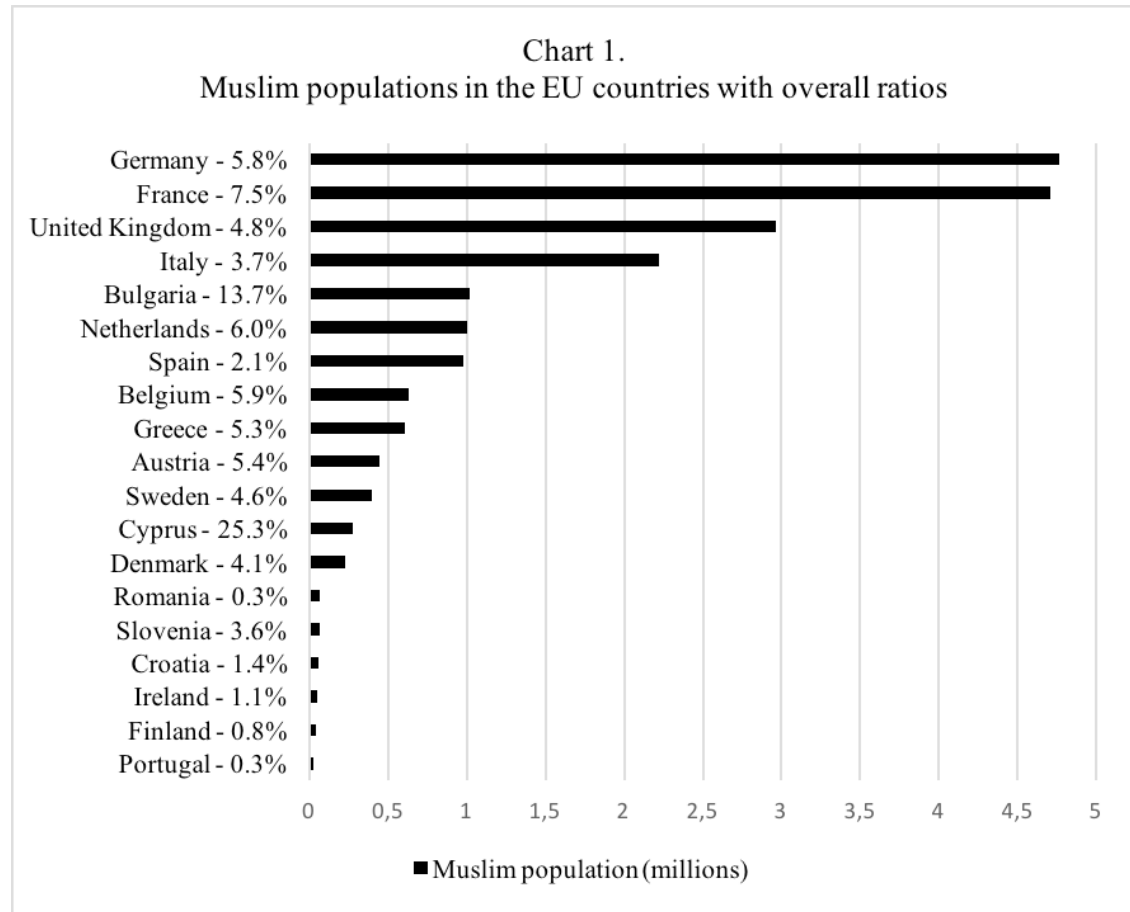

The chart has been prepared by the author with the data collected from Pew-Templeton Global Religious Futures Project, 2016.

called Eurabia within the framework of an Islamization of Europe. She used the terms Islamization and Arabization synonymously (Ye'or 2005, 20 I I), since the process would be the result of Muslim immigration from Arab countries. Within the current conjuncture, Eurabia perfectly matches with the concerns of local Christians regarding the potential risk of mass Muslim immigration to European identity.

In terms of the religious leanings of European societies, it has been Judeo-Christian characteristics that have shaped their cultural codes (Göle 2015: 58). The issues that Muslims have faced in terms of religious freedom have been overcome before by a different religious group. In Germany, for instance, issues such as the building of synagogues, wearing kippah in courthouses and not being able to fulfil requirements of Sabbath have been referred as worrying in similar ways as today's issues (ibid. 24I). However, the reason why the cultural codes have been shaped around Judeo-Christian characteristics, in addition to its Greco-Roman roots, is a moral agreement that Europe had managed to come to with Judaism, as stated by Göle (ibid. 
238). The third monotheistic religion, Islam, on the other hand, has become the one that is possessed by newcomers, and with the manifest differences of Muslims in terms of dress and/or religious practices, their existence has been considered to be incompatible with already-existing cultural codes. Within this debate concerning difference in cultural codes, Tariq Madood (2007) indicates a cultural racism, which focuses on both cultural and ethnic differences, in order to analyse the anti-Muslim approach. Hence, the term racism is being evolved into a term for the action of offensively supporting superiority, not only of colour, race or ethnic difference, but also cultural codes. Claudia Winkler (20 I 4) highlights the same issue with the term neo-racism, which similarly focuses on cultural differences, and adds that in terms of neo-racism Islam is not considered a religious faith, but it is reduced to a set of cultural codes which cannot be compatible with human rights that the enlightened European culture adopts itself. John Esposito (201 I), as well, claims that anti-Islamic attitudes come close to racism.

Islamophobia is defined as negative attitudes and/or feelings about Islam and Muslims, which can be gathered as anti-Islamic attitudes. The term's outstanding definition in the Runnymede Trust's report entitled Islamophobia: A Challenge for Us All ( ( 997) highlights its unfairness and the fear and hatred which targets the entire, or majority, Muslim population. In contrast with scholars who highlight the term's closeness to racism, Vincent Geisser (2003) claims that it should be considered as different from racism, identifying it as a phobia of religion. He expresses this distinction from racism in terms of its target group. While the victim tends to be the group which differs from the majority, it is the majority within this context. Instead of Muslims, who have been seen as others in the society, it is the Europeans who are victims here, as they feel attacked in terms of own identity due to Islamization resulting from an invasion of Muslims. Erik Bleich (201 I: I593), similarly, focuses on the consequences of mass immigration which have brought about and/ or deepened Islamophobic sentiments towards Muslim immigrants within a cause and effect relationship. Hence, Islamophobia becomes a marker in terms of identity between those who fear becoming a minority in terms of the emergence of Eurabia and the consequences of Muslim invasion, and those who possess religious differences.

Muslims, who are 'the other' in the context of European society, possess and demonstrate significant differences in terms of religious and/or cultural codes, including, for example, the building of mosques and minarets, the 
demand for halal meat, and the wearing of headscarves. Identity is a collection of responses to the question that asks 'who am I?' and these responses position one in relation to the other. Sometimes one positions oneself as an individual, while at certain times the need to be a part of a society occurs and social identity has dominance over individual identity. In other words, individuals tend to engage in self-description with respect to membership of a social structure (Mlicki and Ellemer I 996: 98). Social Identity Theory analyses one's social identity in terms of group dynamics and inter-group relations. In accordance with the inter-group relations, each in-group, to which individuals bind themselves, has out-groups, and they position themselves in order to compete, to possess dominance over these out-groups, and ultimately to increase their self-respect (Turner 1982: 33).

Margaret Hogg ( 1993: 107) highlights two particular causes why individuals tend to bind themselves to a social category; there should either be discrimination or a significant threat coming from an out-group. It is certain that the EU members on which this paper focuses compose a wide target group and every one of these countries has various historical processes in terms of their interaction with Islam. However, with respect to the current dynamics of the interaction, newcomer Muslims generate one out-group for one unique in-group which is composed of local Christians from various countries and different national identities. Hence, within this intergroup conflict there are two social identities which have inner diversity in themselves, and both of the groups have their own complaints, even if they are not entirely hostile (Göle 20 15:22-3). Certain local groups fear to lose social dominance in their homeland and become minorities in their own culture. On the other hand, newcomer Muslims complain about increasing Islamophobia, being questioned in terms of their religious and cultural possessions and positions, alongside not sharing the same cultural components with locals. Besides, in accordance with the theory, in-group members tend to exalt their social category by using stereotypes which give them dominance over out-groups, and it is not rare to use exaggerated stereotypes (Demirtaş 2003: $\mathrm{I}_{3} \mathrm{I}-4$ ). Islamophobia, within this context, paves the way for encouragement of this inter-group conflict with exaggerated anti-Muslim components.

Oxford Dictionaries annually announce a word of the year which reflects a global trend, and it will vary significantly in terms of its meaning. For instance whilst in 2015 it was the emoji 'face with tears of joy', for 2016 , the 
chosen word, post-truth, was by contrast strongly political, a consequence of a globally polarised world politics. The word 'post-truth' was not a new word, however, but it was perfectly suited to the political atmosphere of the international system. Its meaning has been defined by Oxford Dictionaries (20I6) as follows: 'relating to or denoting circumstances in which objective facts are less influential in shaping public opinion than appeals to emotion and personal belief'. The term has been adopted by political commentators and 'post-truth politics' has found a significant base in political analysis. Its exaggerated negative outcomes have started to be used by right-wing populist parties as a political tool in order to shape public opinion. Posttruth political discourses composed of anti-Islamic and anti-immigrant approaches have gathered significant support, as has been visible in poll results, and this has paved the way for consciousness of differences between these two sections of society.

The distinction between the other and us can be applied in various ways. For the purpose of the present study, religious difference plays a significant role. Resistance to progressive cultural change can explain the importance of religious difference, which applies in not only religious but also cultural components, as mentioned above. However, in terms of a rise of populism there are various effects that should be focused on. Economic insecurity and social deprivation have salient effects on the electoral behaviour of those left behind, a group composed of low-waged, unskilled workers, long-term unemployed, and poorer white populations living in suburban areas within, or close to, settlements of immigrants (Inglehart and Norris 2016). Populist movements' representatives use the evidence of inequality to blame others for a decrease in public services and job opportunities for $u$ s. Their discourses, stressing both cultural and economic conditions, easily find a home within aforementioned composition of inter-group relations since societies become vulnerable to reactionary populist references and support them due to negligence of their privileges.

\section{The political atmosphere and recent elections in the EU}

As in the global context, the political order in the EU has become polarised in recent years. In various EU countries, populist parties have gained more power over the past decade. In order to demonstrate the rise of populism in the EU within the context of the presence of Muslims, anti-immigrant and anti-Islamic discourses - among all the other Eurosceptic ones 
- will be focused on before examining the support the voters have given to those parties.

In Germany, the populist movement is led by the Alternative for Germany (Alternative für Deutschland, AfD) and headed by Frauke Petry, a former businesswoman. Petry's and other AfD representatives' current declarations mostly focus on fears of terrorism and the problems of refugees integrating into German society, and they are characterised by an extreme anti-immigrant approach. In January 20I6, she was criticised strongly for her suggestion that the German police should shoot immigrants who cross the border illegally. Despite criticisms, the party manifesto concerning relations with Muslims, stressed another topic; 'Islam is not a part of Germany' (Robins-Early 20I7). In the political arena, in addition to AfD, there is an anti-Islamic movement called Patriotic Europeans Against the Islamization of the West (PEGIDA), formed in Dresden in 20I4. It has carried out protests against the arrival of migrants not only in Germany but in several cities in Europe which are concerned about rising Muslim populations, to which I. I million refugees were added in 20 I $_{5}$, due to increased numbers of asylum applications (Reuters 2016).

In Austria, where the Freedom Party of Austria (Freiheitliche Partei Österreichs, FPÖ) leads the populist movement, this far-right political movement is still linked with racism in connection with neo-Nazis. FPÖ representatives' declarations have been criticised strongly due to its hostility towards Jews; however, with the leadership of Heinz-Christian Strache the target of the hatred was shifted from Jews to Muslims. Strache referred to political Islam as a new form of fascism, with which he believes it is necessary to fight (Shuster 20I6). Norbert Hofer, a member of the party, ran for the presidency in the Austrian presidential election of 2016 and became a very competitive candidate in the election process. His promises demonstrated significant similarity with entire populist right-wing representatives' discourses in various countries; he campaigned on border controls in order to secure the country from immigrants, limiting benefits that immigrants enjoy, and favouring Austrians in terms of employment. As a proof of its Eurosceptic approach, the motto of the FPÖ is 'Austria first' (The New York Times 2016).

In the Netherlands, Geert Wilders is notorious for his visible opposition to the presence of Muslims and unsympathetic approach to Islam. His opposition is systematised in Dutch politics in the Party for Freedom (Partij voor de Vrijheid, PVV). PVV is not merely opposed to Islam, since its 
policies are composed of further arguments of a Eurosceptic character. He has publicly stated that his intention is to ban the Quran, exclude Muslim Dutch people from dual citizenship in cases of having a criminal record and to ban mosques and Islamic schools (Robins-Early 20I7). The support that he has gained for his anti-immigrant, Islamophobic and anti-EU discourses has increased markedly throughout the decade.

In France, Marine Le Pen is a public figure whose statements reflect a strong nationalist tendency composed of Eurosceptic and anti-Muslim contents. During her French presidential election campaign of 2017 , she promoted ideas such as border controls to secure the country against Islamist terrorism and Muslim immigrants, a return to the national currency and full exit from the EU (Robins-Early 2017). The party that she leads, the National Front (Front National, FN), had run a very competitive campaign in terms of opposing Islam and immigration and received significant support from voters, since it promised to reduce the number of immigrants entering into the country as well as to implement a protectionist approach to economic policies, for example, limiting government expenditure on immigrants, including healthcare (The New York Times 2016).

In Greece, the Golden Dawn, a far-right populist party, has played a significant role in terms of rising populism in the country. Representatives of the Golden Dawn remained silent during debates concerning the possible expulsion of the country from the Schengen Area for being the first country in which illegal entry to the EU was happening; however, they marched in protest at the presence of newcomers in places where refugee camps were being settled. Golden Dawn's most salient practice was referring to Donald Trump's election as the president of the USA as a victory against 'illegal immigration' in favour of 'ethnically clean states' (The New York Times 2016).

In Hungary, Jobbik, the Movement for a Better Hungary (Jobbik Magyarországért Mozgalom) represents a right-wing populist movement in the political arena. The Jobbik Movement's arguments, composed of antiMuslim and Eurosceptic discourses including economically protectionist policies, have been salient in national politics (The New York Times 2016). Additionally, Victor Orbán, the Prime Minister and leader of the national conservative political party, Fidesz, also represents populist ideas in support of the Jobbik movement (BBC News 2016). 
In Sweden, the Swedish Democrats (Sverigedemokraterna) is the representative party of right-wing populist ideas. It refers to mass immigration as an issue in economic and social affairs (Sharman 2017) and supports white supremacism as well as promoting a referendum on Sweden's membership of the EU (The Nerw York Times 2016).

Representatives of right-wing populist movements are not limited to the aforementioned parties: there is also Flemish Block (Vlaams Blok, VB) in Belgium, the Danish People's Party (Dansk Folkeparti) in Denmark, the Finns Party (Perussuomalaiset) in Finland and Kotleba - People's Party Our Slovakia (L'udova strana Naše Slovensko) in Slovakia. These parties similarly support anti-Muslim and Eurosceptic discourses. Alongside mobilised political and social movements, there have been individual declarations that encourage a polarisation of Muslims and local communities. Discriminatory speeches by prominent political figures possess significant importance in terms of social tendencies on a particular topic due to the power of shaping public opinion they can have. One such unfortunate declaration was made by Robert Fico, the Slovakian Prime Minister, in 2016, in which he mentioned that 'Islam has no place in Slovakia', causing significant controversy (Boccato 20I6). His statement was supported by Victor Orbán. In addition to Orbán's strong nationalist approach in domestic and foreign policies, he, like Robert Fico, has highlighted the necessity of defending Christian culture against not only Muslims but also all foreigners in the country (Foster 2016). As another example, Robert Winnicki, leader of the National Movement (Ruch Narodowy) in Poland, addressed demonstrators with following statement: 'We're demonstrating against the Islamization of Europe, we're demonstrating against immigration, against an invasion' and encouraged protests against Muslims (Reuters 20I6).

In certain cases, anti-immigrant discourses have descended to the level of anti-Islamic ones. For instance, Robert Fico offered to take 200 Syrian refugees, but only those who are Christian, citing a lack of mosques in the country. However, his policy was criticised strongly for its religion-based discriminatory approach as officials started to mark asylum seekers with numbers on their arms. This action's defence was that it was a means to facilitate the process of identification of those who did not speak any common language; nevertheless, this explanation failed to calm the critics down. In the end, they ended the application (Lebor 2015). Estonia, Bulgaria and Poland responded to EU directive pressure to share refugees among 
member countries on one condition; they declared that they would allow only Christian asylum seekers to enter the country, or they would not let in any (Shuster 2016).

The polarised atmosphere has been even more visible during the campaigns of recent elections. Since 2016, there have been four elections in four EU member states and leaders of the right-wing parties have attracted significant attention with significant anti-immigrant and anti-Islamic statements.

Norbert Hofer, a member of the Austrian FPÖ, ran for presidency in the 2016 presidential elections. As shown in Chart 2, he narrowly lost the election, winning 48.3 per cent of the vote (Oliphant and Csekö 20r6).

In 2017, the Dutch PVV gained I3.I per cent of the vote, whilst Geertz Wilders increased the share of power he had gained in previous elections. As shown in Chart 3 , the PVV is currently represented by 20 seats in parliament (Henley 201 7 ).

Chart 2. Austrian presidential elections 2016

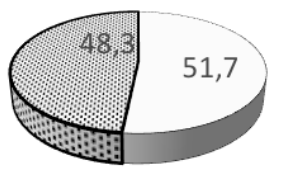

- Alexander Van der Bellen

CNorbert Hofer

The chart has been prepared by the author using official election results.

Chart 3. Number of seats in Dutch general elections 2017

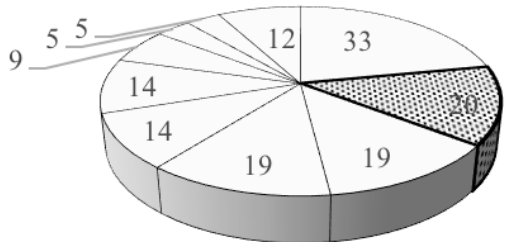

口VVD - liberals - 33

-CDA - Christian Democrats - 19

口GL - Greens - 14

口PvdA - Labour - 9

口PvdD - Pro Animals - 5
DPVV - anti-immigration - 20

DD66 - Liberal Progressives - 19

口SP - Socialists - 14

口CU - Christian Union - 5

DOthers - 12

The chart has been prepared by the author using official election results. 
Chart 4.

French presidential elections 2017

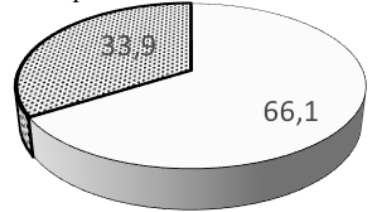

DEmmanuel Macron

Marine Le Pen

The chart has been prepared by the author using official election results.

Chart 5. Number of seats in German federal elections 2017

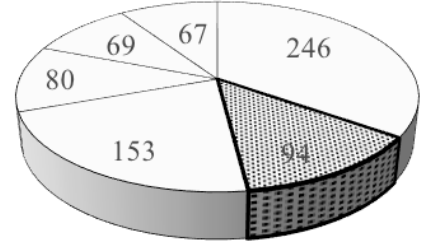

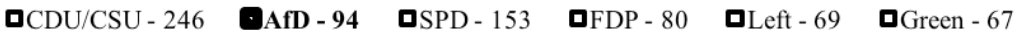

The chart has been prepared by the author using official election results.

Later in 2017 , French presidential elections were held and Le Pen ran for office. The leader of the FN lost the elections with 33.9 per cent of the votes as shown in Chart 4 (Eleftheriou-Smith 2017).

The results of the aforementioned elections were monitored with significant anxiety within the European political scene since each populist movement within the EU asserts Eurosceptic discourses which call for a return to national identity, which is said to have been damaged by the rise of a common-European understanding of identity. After each election, European leaders have publicly stated their concerns about the future of the EU (Paterson 2016, Rosemain and Blamont 2017, Henley 2017).

The latest elections to be held which are within the focus of this research were the German federal elections of September 2017. Far-right ideology here has barely had any supporters since the era of the National Socialist Party; however, there was a significant rise in support for the AfD during these elections. The rise of AfD had been foreseen for the federal elections, 
since it had already gained salient support from voters in the local elections of September 20r6. Even more than expected, however, AfD gained I 2.6 per cent of the vote and as shown in Chart 5, it is currently being represented by 94 seats in the German Parliament, Bundestag (Der Bundeswahlleiter 20I7). This is the first time since the era of the National Socialist Party that a far-right political party has been represented in the Bundestag.

\section{The failure of parties vs. millions of votes}

The results of the recent elections have been described above, and as can be seen all four representatives of populist movements in four countries have failed to win the elections despite their increased share of the votes. If the period of time under examination is taken back to 2014 , the year when massive flows of refugees began to head towards the EU countries, the picture will not change.

Since 2014, there have been seven elections in seven different EU member countries. The reason why 2014 has been selected as the starting point is because anti-immigrant discourses have found their place on the political agenda since then, in addition to already-existing anti-Islamic ones. When the elections results are considered, taking into consideration differences in election systems, it is clear that none of these parties have become a party in power, nor have any of the party's leaders become the president. However, there are millions of votes which these parties have gained as a consequence of their anti-immigrant and anti-Islamic discourses.

Chart 6 has been prepared with respect to official election results. In 20 I 4 in Hungary the Jobbik Movement gained 1.02 million votes in the parliamentary elections (Mudde 2014), and the Swedish Democrats gained o.8 million votes in the general election (New York Times 20I6). A year later, the Danish People's Party gained 0.74 million votes in the general election (BBC News 2015), True Finns gained 0.52 million votes in the Finnish parliamentary elections (Statistics Finland 2015), and Golden Dawn gained 0.39 million votes in the Greek legislative elections (The Economist 201 5). In 20I6, the leader of the Freedom Party in Austria gained 2.I million votes in presidential elections (Oliphant and Csekö 20r6); and in Slovakia, Kotleba - People's Party Our Slovakia gained 0.2 I million votes in the parliamentary election (Mesežnikov 2016). In 2017, the Party for Freedom gained I.37 million votes in the Dutch general election (Henley 20I7), the leader of the National Front gained Io.64 million votes in the French presidential 
Chart 6. Number of votes for populist right wing parties in the EU since 2014

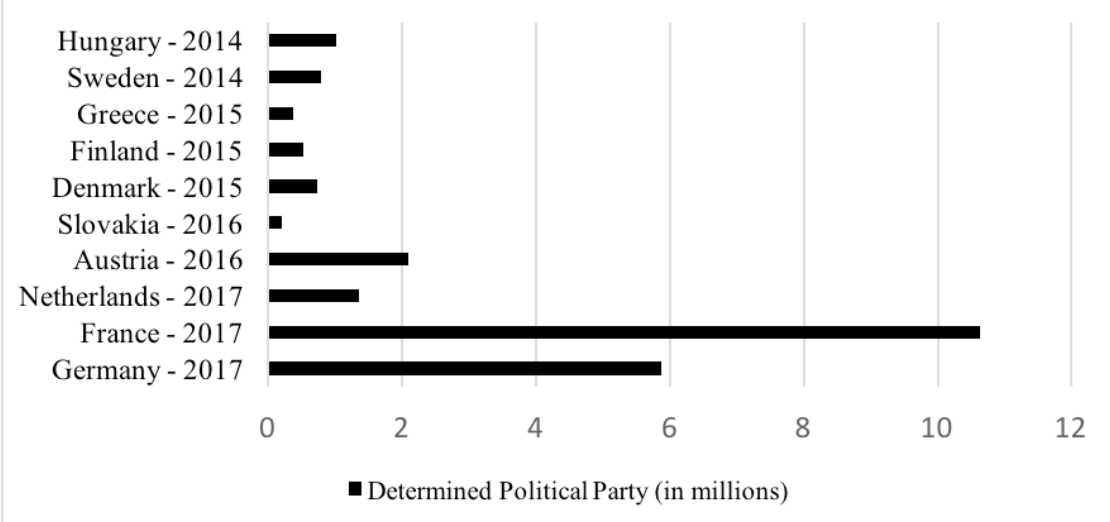

The chart has been prepared by the author using official election results.

elections (Eleftheriou-Smith 2017) and Alternative for Germany gained 5.88 million votes in the German federal elections (Der Bundeswahlleiter 20I7). The listed parties have gained millions of votes in total around the $\mathrm{EU}$ and in addition to the salient numbers of votes, demonstrating the support of voters, in parliamentary elections these parties have won seats. It means that the discriminatory politics of these parties will be represented at different levels of national politics, including the executive order, with respect to the political system of each country.

\section{Reality vs. perception}

The anti-Muslim discourses, alongside Eurosceptic statements, of the party representatives of the right-wing populist parties have provided them with a significant share of the vote in various member states of the EU. Despite the actual failure of these parties - they could not get sufficient votes to get into power or presidency - their approaches have formed a base among their voters. The most important question for the purpose of this research is whether this threat is as real as it is advertised to be by representatives of these parties, or not?

During a campaign event in Berlin, run by AfD in September 2016, Georg Pazderski, a party member, answered the question as to why the Germans fear the massive influx of immigrants, even if the immigrants are 


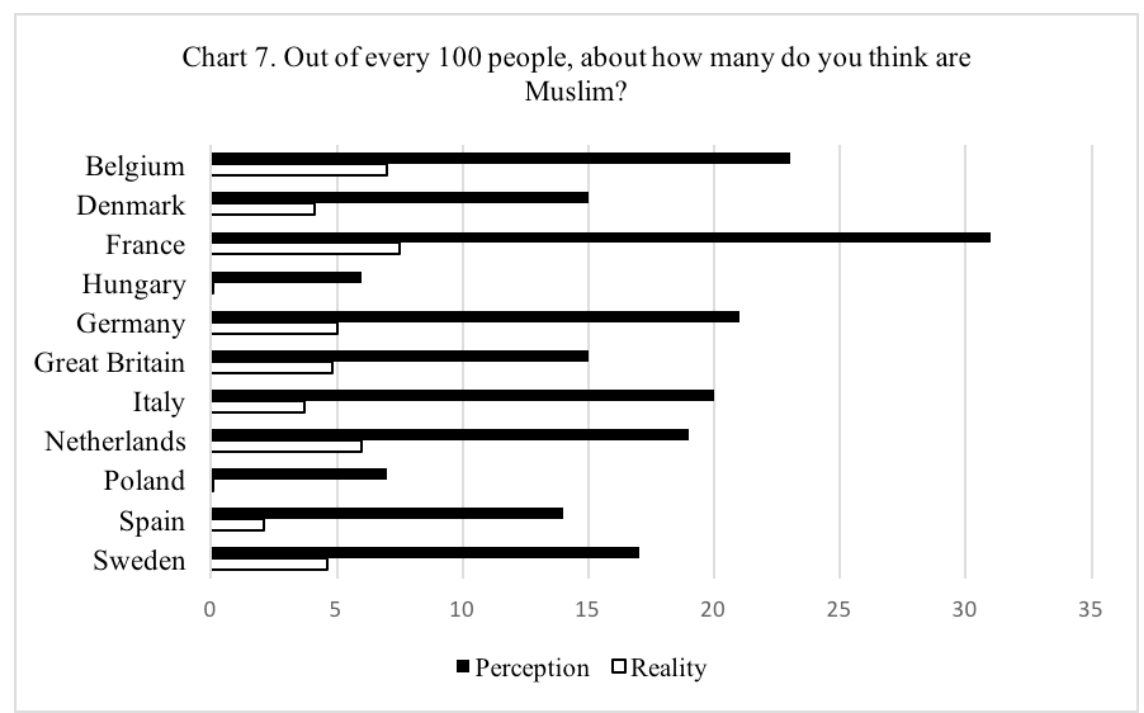

The chart has been prepared by the author with the data collected from The Perils of Perception, 2016.

not causing an increased crime rate, as follows: 'Perception is reality... What people feel is what they perceive as reality. And at the moment, our citizens feel unwell, insecure' (Shuster 2016). His statement demonstrates an important link between the characteristics of current politics and the general emotional status of the social context. Perceptions have more power than the reality since they deeply affect voters' choices during elections. Party representatives have the ability to manipulate the reality and shape public opinion according to the tendency that political interests would like to create. This is what Georg Pazderski mentioned in his statement. Even though there is no increase in recorded crimes involving immigrants, representatives of political parties have the power to suggest that there is such an increase.

In terms of perception, research has been carried out by IPSOS in which people were asked their opinions concerning the population of Muslims in their own country. The research was carried out in 40 countries in 2016 and member countries of the EU are shown in Chart 7. There is a significant discrepancy between the actual numbers and the perceptions. The subjects of the research made their own guesses with respect to their perceived understanding concerning the presence of Muslims in their respective countries. Their guesses were exaggerated the numbers, since they had been hearing about the problems that Muslims have been said to be the cause of, and had 
been seeing them more often in the news. With the power of the media and politics, it is not difficult to shape public opinion. Once it is believed that there is significant number of Muslims in the country, locals start to believe, for example, that newcomers may cause more problems and locals may lose their own identities, Europe may be Islamized due to increasing numbers of Muslim newcomers. Unavoidably, this fear would lead locals to become more distant from reality; in other words, that fear would cause a feedback loop concerning the relationship between a perceived presence of Muslims in contrast to the reality and the fears concerning Muslim presence.

\section{Conclusion}

The EU has been structured on the basis of proper values, both at domestic and international levels. The constituted European identity, which was stated officially in the Declaration of European Identity in 1973 by nine members of the European Community, has been composed with respect for the rule of law, social justice, human rights and democracy for its citizens and according to the responsibilities of its members and the rest of the world. These values and characteristics united the societies under one European identity (Kostakopoulou 2016).

In terms of identity, the notion of 'Eurabia' as part of a conspiracy theory, has become a very significant challenge for European societies since they have felt under attack due to increased numbers of Muslims within their own societies. Not only recent massive flows of refugees but also the further integration of earlier generations of Muslims who arrived during the second half the twentieth century have brought the debate to the table once again. Beginning with the New York attacks of I I September 200 I and currently with the attacks of the ISIL, collective consciousness has focused on security issues relating to Islamist movements and, as an unfortunate fact, with Muslims. These threats concerning both security and identity related issues have empowered the spread of Islamophobia among certain parts of European society. The reaction was consolidated in terms of opposition towards Muslims, in addition to the perception that Islam was not coeval with European values. Consequently, the said reaction has caused local Christians to bind their group identity and within the context of intergroup conflicts Islamophobia has provided them with inflated arguments concerning the presence of Muslims. 
Perception possesses the power to get beyond the bounds of reality at certain times. As discussed in earlier sections of this research summary, posttruth political tools have gained significant importance in world politics, creating perceptions which differ from the reality and with the power of populist discourses and the vulnerability of certain sections of the society, people tend to support these political movements. The fact of an increasing number of Muslims in the society is a reality; however, the risks that they are said to represent are the components of perception. Alongside various other components, including economic and social ones, the presence of Muslims is represented as a real threat, and these anti-Muslim discourses have been used for the political ends of right-wing populist parties, to support their strong nationalist and Eurosceptic approaches. The support that they have gained has become concretised in increased shares of the vote, as has been illustrated above in various elections in member states of the EU.

The EU is an active international actor in the international system not only because of its political power, but also because of its values. However, the rise of populism, with the support of strong anti-Muslim and Eurosceptic discourses, have brought about worries in terms of these aforementioned European values and identity. Reaction to the surge in refugees and a consequent 'turn inwards' (Kostakopoulou 2016) of the EU in terms of international problems, and the way that the EU has handled the massive flows of refugees, which was referred as clumsy by Federica Mogherini, the EU's Foreign Policy Chief, have been degrading its effectiveness in the international system (Paterson and Cendrowicz 201 5). The then head of the UNHCR and current Secretary General of the United Nations, António Guterres, criticised the rise of anti-immigrant discourses:

As anti-foreigner sentiments escalate in some quarters, it is important to recognize the positive contributions that refugees and migrants make to the societies in which they live and also honour core European values: protecting lives, upholding human rights and promoting tolerance and diversity. (UNHCR 20I5)

The way that the EU has gone in terms of handling the issue of refugees has been considered to be a collective weakness (Lehne 2016).

As can be seen in the ways information is perceived in these social contexts, public opinion has been shaped by post-truth political tools which 
bring about illusory scenarios of crisis which are encouraged by right-wing political party representatives. This false perception has led EU politics into a general tendency which is characterised by a shift towards rightwing populism. This populist tendency started to gain momentum not only within national politics but also at the level of European politics, since the movement is represented by MEPs in the European Parliament. The rise of populism goes alongside Euroscepticism, and if this rise keeps on, Euroscepticism will strengthen. This would bring about nothing but a real crisis for the EU itself.

Dr Didem Doganyilmaz Duman is assistant professor of Political Science and International Relations at Halic University in Istanbul/Turkey and external contributor at the UNESCO Chair of Intercultural Dialogue in the Mediterranean in Tarragona/Spain. She focuses on politology of religion with specific interest in interreligious affairs, religion-based identity conflicts, interrelationship between religion and politics, and politics of laicism and secularism. She has several conference presentations and publications related to these topics.

\section{References}

BBC News, 20 I 5. 'Danish election: opposition bloc wins', BBC News, I 9.6.20 I 5 , <http://www.independent.co.uk/news/world/europe/french-electionresults-20I 7-marine-le-pen-third-spoiled-ballots-abstentions-emmanuelmacron-a77237 I I.html> (accessed I0.4.20I 7)

-2016. 'Guide to nationalist parties challenging Europe', BBC, 23.5.2016, $<$ http://www.bbc.com/news/world-europe-36r 30006> (accessed 2.8.20I7)

Bleich, Erik, 20 I I. 'What is Islamophobia and how much is there? Theorizing and measuring an emerging comparative concept', American Behavioral Scientist, 55(I 2), pp. I 58 I-I 600

Boccato, Angelo, 2016. 'Brexit - where refugee crisis meets identity crisis', Equal Times, 20.6.20I6, <https://www.equaltimes.org/brexit-where-refugeecrisis-meets?lang=en\#.WaGrCFdoWT_> (accessed 3.8.20I 7$)$

Clayton, Jonathan, and Hereward Holland, 20 I 5 . 'Over one million sea arrivals reach Europe in 2015', The UNHCR, 30.12.2015, <http://www.unhcr.org/ news/latest/20 I 5/ I 2/5683 dob 56/million-sea-arrivals-reach-europe-20 I 5 . html> (accessed I0.5.20I7)

Demirtaş, H. Andaç, 2003. 'Sosyal Kimlik Kuramı, Temel Kavram ve Varsayımlar', İletişim Araştırmaları Dergisi, I( ( ), pp. I 23-44

Der Bundeswahlleiter, 20 I 7. 'Bundestagswahl 20г 7', Der Bundeswahlleiter, 25.9.2017, <https://www.bundeswahlleiter.de/bundestagswahlen/201 7 / ergebnisse/bund-99.html> (accessed I I.I 2.20I7) 
Doganyilmaz Duman, Didem, 20r6. 'Alevi - Bektashi belief in Balkans: a historical legacy', Balkan Social Science Review, 7, pp. 67-87

The Economist, 20 I 5 . 'Syriza wins', The Economist, 25. I.20 I 5, <https://www. economist.com/blogs/graphicdetail/2O I 5/or/greeces-election> (accessed I.8.2017)

Eleftheriou-Smith, Loulla-Mael, 20 I 7. 'French election results: the case for saying Marine Le Pen actually came third', Independent, 8.5.201 7, <http:// www.independent.co.uk/news/world/europe/french-election-results20I7-marine-le-pen-third-spoiled-ballots-abstentions-emmanuel-macron-a77237 Ir.html> (accessed I.8.2017)

Esposito, John L, 20 I I. 'Islamophobia: a threat to American values?' Huffington Post, 25.5.20 I . <http://www.huffingtonpost.com/john-1-esposito/islamophobia-a-threat-to_b_676765.html> (accessed I0.4.20I 7 )

European Commission, 2016. 'EU-Turkey statement: questions and answers', European Commission, I 9.3.2016, <http://europa.eu/rapid/press-release_ MEMO-ı6-963_en.htm> (accessed I.I2.2017)

Foster, Peter, 2016. 'The rise of the far-right in Europe is not a false alarm', Telegraph, I 9.5.2016, <http:/www.telegraph.co.uk/news/2016/05/19/therise-of-the-far-right-in-europe-is-not-a-false-alarm/> (accessed 2.5.20I 7$)$

Geisser, Vincent, 20r 3. La nouvelle Islamophobie (Paris, La Découverte)

Göle, Nilüfer, 2o ı o. $\dot{I}_{\xi} \dot{I}_{c ̧}$ Girişler. İslam ve Avrupa (Istanbul, Metis Yayınevi) -20 I 5. Gündelik Yaşamda Avrupalı Müslümanlar (Istanbul, Metis Yayınevi)

Henley, Jon, 20 7 7. 'Europe's governments signal relief after Dutch election defeats far right', The Guardian, I6.3.20 I 7, <https://www.theguardian.com/ world/20I $7 / \mathrm{mar} / \mathrm{I} 6 /$ europes-governments-signal-relief-as-dutch-electiondefeats-far-right> (accessed I0.4.20I7)

Hogg, Margaret A. I 993. 'Group cohesiveness: a critical review and some new directions', European Review of Social Psychology, 4, pp. 86- I I 2

Inglehart, Ronald, and Pippa Norris, 20r6. 'Trump, Brexit, and the rise of populism: economic have-nots and cultural backlash', HKS Working Paper, RWP $16-026$, pp. I-52

Kopecky, Petr, and Cas Mudde, 2002. 'The two sides of Euroscepticism: party positions on European integration in East Central Europe', European Union Politics, 3(3), pp. 297-326

Kostakopoulou, Dora, 20 r6. 'European identity and the plight of Syrian refugees', Middle East Institute, 5.4.2016, <https://www.mei.edu/content/map/ european-identity-and-plight-syrian-> (accessed I0.4.2017)

Lebor, Adam, 20 I 5 . 'Angela Merkel: Europe's conscience in the face of a refugee crisis', Newsweek, 9.5.20 I 5, <http://www.newsweek.com/201 5/o9/1 8/ angela-merkel-europe-refugee-crisis-conscience-369053.html> (accessed I0.8.2017)

Lehne, Stefan, 20r6. 'How the refugee crisis will reshape the EU', Carnegie 
Europe, 4.2.2016, <http://carnegieeurope.eu/2016/02/o4/how-refugeecrisis-will-reshape-eu-pub-62650> (accessed 05.05.2017)

Madood, Tariq. 2007. Multiculturalism: A Civic Idea (Cambridge, Polity Press)

Mesežnikov, Grigorij, 2016. 'The 2016 elections in Slovakia: a shock', Heinrich Böll Stiftung, 22.3.2016, <https://cz.boell.org/en/2016/o3/22/2016-elections-slovakia-shock > (accessed I 4.4.20I7)

Mlicki, Pawel P., and Naomi Ellemers, I 996. 'Being ddifferent or being better? National stereotypes and identifications of Polish and Dutch students', European Journal of Social Physcology, 26, pp. 97-I I 4

Mudde, Cas, 20 I 2. 'Three decades of populist radical right parties in Western Europe: so what?', European Journal of Political Research, 52 (I), pp. I-I 9

20I4. 'The 2014 Hungarian parliamentary elections, or how to craft a constitutional majority', The Washington Post, I 4.4.20 I 4, <http://www.independent.co.uk/news/world/europe/french-election-results-201 7-marine-lepen-third-spoiled-ballots-abstentions-emmanuel-macron-a77237 I I.html> (accessed 10.4.2017)

Muis, Jasper, and Tim Immerzeel, 20 I 7. 'Causes and consequences of the rise of populist radical right parties and movements in Europe', Current Sociology Review, 65(6), pp. 909-30

The New York Times, 2016. 'Europe's rising far right: a guide to the most prominent parties', The New York Times, 4. I 2.201 6, <https:/www.nytimes.com/ interactive/20I6/world/europe/europe-far-right-political-parties-listy. html?mcubz=2\&_r=4> (accessed I0.4.20I7)

Nielsen, Nikolaj, 20 I 7. 'EU starts border checks on everyone', euobserver, 7.4.20 I 7, $<$ https://euobserver.com/justice/I37530> (accessed I0.4.2017)

Oxford Dictionaries, 2016. 'Post-truth', Oxford Dictionaries, <https:// en.oxforddictionaries.com/definition/post-truth> (accessed 2.4.20I7)

Oliphant, Roland, and Balazs Csekö, 20 r6. 'Austria election: Far Right leader Norbert Hofer concedes defeat to Alexander Van der Bellen', The Telegraph, 5.I 2.20I6, <http://www.telegraph.co.uk/news/2016/I 2/o4/austriaelection-norbert-hofer-cusp-becoming-europes-first-far/> (accessed I0.4.2017)

Paterson, Tony, 2016. 'Austria: European leaders celebrate defeat for far-right Hofer as "the liberal majority pushes back"', Independent, 4. I 2.2016, <http://www.independent.co.uk/news/world/europe/austria-electionresult-reaction-far-right-norbert-hofer-loser-a 7455486.html> (accessed I 0.4 .2017 )

Paterson, Tony, and Leo Cendrowicz, 201 5 . 'Refugee crisis: divisions leave Europe paralysed as borders close to refugees', Independent, I 5.9.20 I 5, <http:// www.independent.co.uk/news/world/europe/refugee-crisis-divisions-leaveeurope-paralysed-as-borders-close-to-refugees-I0502706.html> (accessed I0.4.2017) 
Rankin, Jennifer, 2016. 'EU refugee crisis: asylum seeker numbers double to I.2m in 201 5', The Guardian, 4.3.2016, <https://www.theguardian.com/ world/2016/mar/o4/eu-refugee-crisis-number-of-asylum-seekers-doubledto-I 2-million-in-20I $5>$ (accessed I.I2.20I 7)

Reuters, 2016. 'Anti-Islam movement PEGIDA stages protests across Europe', Reuters, 6.2.2016, <http:/www.reuters.com/article/us-europe-migrantsprotests-germany-idUSKCNoVFoP $4>$ (accessed I 2.4.20 I7)

Robins-Early, Nick, 20I 7. '20I 7 will test the rise of Europe's populist far-right', Huffington Post, I 2.1.201 7, <http://www.huffingtonpost.com/entry/europepopulist-far-right_us_58756 Ibce4bo3c8ao2 $\mathrm{d}_{3}$ cego $>$ (accessed 2.8.20I 7 )

Rosemain, Mathieu, and Matthias Blamont, 2017. 'Macron wins French presidency, to sighs of relief in Europe', Reuters, 7.5.201 7, <http://www.reuters. com/article/us-france-election-idUSKBN I $83003>$ (accessed 5.8.2017)

Runnymede Trust, 1997. Islamophobia: A Challenge for Us All (London, Runnymede Trust)

Rydgren, Jens, 2005. Movements of Exclusion: Radical Right-wing Populism in the Western World (New York, Nova Science Publishers)

Sharman, Jon, 20r 7. 'Anti-immigrant party takes first place in Sweden, poll shows', Independent, 25·3.201 7 , <http://www.independent.co.uk/news/world/ europe/anti-immigrant-sweden-democrats-yougov-poll-first-most-popular-refugee-a7649506.html> (accessed I.5.2017)

Shuster, Simon, 2016. 'European politics are swinging to the right', Time, 22.9.20I6, <http://time.com/45040 Io/europe-politics-swing-right/> (accessed I.8.2017)

Soliman, Asmaa, 20 I 7. European Muslims Transforming the Public Sphere: Religious Participation in the Arts, Media and Civil Society (London, Routledge)

Statistics Finland, 20 I 5. 'The Centre Party of Finland victorious in the parliamentary elections 201 5', Statistics Finland, 30.4.20 15, <http://www.stat.fi/til/ evaa/20I5/evaa_20I5_20I5-04-30_tie_oor_en.html> (accessed 20.4.2017)

Taggart, Paul, I 998. 'A touchstone of dissent: Euroscepticism in contemporary Western European party systems', European Journal of Political Research, 33, pp. $363-8$

Taggart, Paul, and Aleks Szczerbiak, 2002. 'The party politics of Euroscepticism in EU member and candidate states', Opposing Europe Research Network Working Paper, 6 (Sussex European Institute)

Pew-Templeton Global Religious Futures Project, 2or6. 'The Future of World Religions', Pew-Templeton Global Religious Futures Project, <http:// globalreligiousfutures.org> (accessed I0.4.2017)

The Perils of Perception, 2or6. The Perils of Perception 2016 Survey, Ipsos, $<$ https://perils.ipsos.com> (accessed I.4.20I7)

Turner, John G, I982. 'Towards a cognitive redefinition of the social group', in Social Identity and Intergroup Relations, ed. Henri Tajfel (Cambridge University Press), pp. I 5-40 
UNHCR, 2015. 'A million refugees and migrants flee to Europe in 201 5', UNHCR, 22.I 2.20 I 5, <http://www.unhcr.org/56791 8556.html> (accessed I 4.4 .2017$)$

Winkler, Claudia, 2014. 'Neoracism in Europe and its effect on Muslims in the public sphere', Religious Freedom Project, Georgetown University, $<$ https://berkleycenter.georgetown.edu/essays/neoracism-in-europe-andits-effect-on-muslims-in-the-public-sphere> (accessed 2.I 2.20I4)

Ye'or, Bat, 2005. Eurabia: The Euro-Arab Axis (New Jersey, Fairleigh Dickinson University Press)

20 I. Europe, Globalization, and the Coming of the Universal Caliphate (New Jersey, Fairleigh Dickinson University Press) 